Abstracta Iranica Abstracta Iranica

Revue bibliographique pour le domaine irano-aryen

Volume 42-43 | 2021

Comptes rendus des publications de 2019-2020

\title{
Adam Carter Bremer-Mccollum. "The Adoration of the Magi: A New Translation and Introduction"
}

Christelle Jullien

\section{(2) OpenEdition}

1 Journals

\section{Édition électronique}

URL : https://journals.openedition.org/abstractairanica/54094

DOI : 10.4000/abstractairanica.54094

ISSN : 1961-960X

Éditeur :

CNRS (UMR 7528 Mondes iraniens et indiens), Éditions de l'IFRI

Référence électronique

Christelle Jullien, «Adam Carter Bremer-Mccollum. "The Adoration of the Magi: A New Translation and Introduction" », Abstracta Iranica [En ligne], Volume 42-43 | 2021, document 18, mis en ligne le 30 décembre 2021, consulté le 02 janvier 2023. URL : http://journals.openedition.org/abstractairanica/ 54094 ; DOI : https://doi.org/10.4000/abstractairanica.54094

Ce document a été généré automatiquement le 2 janvier 2023.

Tous droits réservés 


\title{
Adam Carter Bremer-Mccollum. "The Adoration of the Magi: A New Translation and Introduction"
}

\author{
Christelle Jullien
}

\section{RÉFÉRENCE}

Adam Carter Bremer-Mccollum. "The Adoration of the Magi: A New Translation and Introduction" in T. Burke (ed.). New Testament Apocrypha: More Noncanonical Scriptures, vol. II. Michigan/Cambridge, U.K.: William B. Eerdmans, 2020, p. 3-12.

1 Nouvelle traduction du texte avec brève présentation de l'état de la recherche et des manuscrits. Ce récit développe une tradition sur les mages évangéliques venus à Bethléem qui mêle à la fois des éléments narratifs de Mt 2, 1-12 et des descriptions cultuelles mazdéennes: ayant reçu en cadeau un morceau de la crèche en pierre où reposait l'enfant Jésus, les mages finissent par s'en débarrasser, ne pouvant ni le porter ni le charger sur leurs montures. Le morceau abandonné dans un puits émet une lumière et un feu, que le narrateur rattache au culte du feu des mazdéens. L'A. participe au projet Nasscal ("North American Society for the Study of Christian Apocryphal Literature"), une clavis des apocryphes chrétiens en ligne et en open access, où le texte se trouve résumé avec les principales données bibliographiques: http:// www.nasscal.com/e-clavis-christian-apocrypha/adoration-of-the-magi. 


\section{AUTEURS}

CHRISTELLE JULLIEN

CNRS, CeRMI, Paris 